\title{
Lead Ions Sorption from Waste Solution Using Aluminum Hydroxide Modified Diatomite
}

\author{
Ying Wang1, Yifeng Lu' ${ }^{1^{*}}$, Rongzhi Chen ${ }^{2 *}$, Lan $\mathrm{Ma}^{3}$, Yong Jiang ${ }^{4}$, Huan Wang5 \\ ${ }^{1}$ School of Life Sciences, Yunnan University, Kunming, China \\ ${ }^{2}$ College of Resources and Environment, University of Chinese Academy of Sciences, Beijing, China \\ ${ }^{3}$ Yunnan Academies of Science and Technology Development, Yunnan, China \\ ${ }^{4}$ YT R D Center (Kunming) for Power and Energy Storage Batteries, Kunming, China \\ ${ }^{5}$ Tianjin Research Institute for Water Transport Engineering, M.O.T., Tianjin, China \\ Email: Iyftoday@126.com, ${ }^{*}$ crz0718@hotmail.com
}

Received 24 March 2014; revised 22 April 2014; accepted 8 May 2014

Copyright (C) 2014 by authors and Scientific Research Publishing Inc.

This work is licensed under the Creative Commons Attribution International License (CC BY).

http://creativecommons.org/licenses/by/4.0/

c) (i) Open Access

\begin{abstract}
This study investigated the effectiveness of aluminum modified diatomite in removing lead from aqueous solution. Scanning electron microscope (SEM), X-ray diffraction (XRD), X-ray Fluorescence (XRF) and infrared spectroscopy were used to characterize the modified absorbents. Effects of several variables like $\mathrm{pH}$, adsorbent dose, initial concentration and the reaction temperature on lead sorption were also investigated. Langmuir and Freundlich isotherm models were applied to describe the equilibrium data. Values of $\Delta H, \Delta G$ and $\Delta S$ illustrated that the adsorption of lead is an endothermic process of nature. Comparing with the natural diatomite, the adsorption efficiency for the lead ions increased from $12.06 \%$ to $61.36 \%$ which indicated that aluminum modified diatomite can be used as a potential absorbent for lead ions.
\end{abstract}

\section{Keywords}

Diatomite, Lead, Adsorption, Aluminum Hydroxide, Modification

\section{Introduction}

The release of heavy metals to the surrounding environment, caused by the development of industries, such as ceramics, metallurgy, mining and battery manufacturing, is becoming a major concern and threatened a lot to the

${ }^{*}$ Corresponding authors.

How to cite this paper: Wang, Y., Lu, Y.F., Chen, R.Z., Ma, L., Jiang, Y. and Wang, H. (2014) Lead lons Sorption from Waste Solution Using Aluminum Hydroxide Modified Diatomite. Journal of Environmental Protection, 5, 509-516.

http://dx.doi.org/10.4236/jep.2014.56054 
human health nearby [1]. Among them, lead ion is one of the biggest issues due to its high toxicity and mobility. In 1988, Nriagu and Pacyna estimated that $635 \times 106 \mathrm{~kg} \cdot \mathrm{yr}^{-1}$ lead had been released into the environment (atmosphere, aquatic systems and soil) due to the mining and metallurgy industry [2]-[4]. Lead spreads into the environment through soils and water streams and accumulates along the food chain, resulting in a high risk to human health, as lead can affect red blood cells, the nervous system, and the kidneys. The lower IQ values and other neuropsychological deficits among the children exposed to higher lead levels have been well documented [5]. Therefore, there was an urgent need to find a solution to reduce lead from water for contamination control and environmental protection. It was reported that there are many approaches for lead removal from water, such as coagulation precipitation, adsorption, ion exchange method, electrolytic process. Among them, adsorption is commonly used and comparatively low cost. The previous reported absorbents that are suitable for the removal of lead ions included natural and modified bauxite tailings [6], diatomite [7], bentonite [8], attapulgite [9], palygorskite [10], and sepiolite [11]. Diatomite is a type of adsorbent with large specific area, high adsorption capacity, and good mechanical properties, broadly utilized in wastewater treatment [12]. Diatomite is regarded as a mineral of organic origin, where the silica of fossilized diatom skeleton resembles opal or hydrous silica in composition (SiO2·H2O). The silica surface contains silanol groups that spread over the matrix of silica [13]. The silanol group is an active one which tends to react with many polar organic compounds and various functional groups. Al-Degs et al. [14] studied the sorption of lead ions on diatomite and manganese oxides modified diatomite. The result demonstrated that manganese oxides modified adsorbent showed a higher tendency for adsorbing lead ions from solution at $\mathrm{pH}$ 4. Khraisheh et al. [15] examined the effectiveness of raw and modified diatomite for the uptake of $\mathrm{Pb}^{2+}, \mathrm{Cu}^{2+}$ and $\mathrm{Cd}^{2+}$ from wastewater. Irani et al. [2] compared lead sorption onto natural perlite, dolomite and diatomite, in which, BET analysis of clays showed that the pore size, surface area and pore volume of diatomite were greater than those of perlite and dolomite. Even so, to our knowledge, little study has been reported for adsorption of lead on aluminum modified diatomite. In this work, the preparation and characterization of aluminum modified diatomite were reported.

\section{Experimental}

\subsection{Adsorbent Preparation}

The diatomite sample was obtained from Tianjin Fengchuan chemical technology co., LTD (China) and it was composed of $\mathrm{SiO}_{2}$ (92.20\%), $\mathrm{Fe}_{2} \mathrm{O}_{3}(1.40 \%), \mathrm{Al}_{2} \mathrm{O}_{3}$ (2.83\%), $\mathrm{CaO}(0.60 \%), \mathrm{MgO}(0.05 \%), \mathrm{K}_{2} \mathrm{O}(0.52 \%), \mathrm{Na}_{2} \mathrm{O}$ (1.91\%) and LOI (0.09\%). Firstly, $3 \mathrm{~g}$ of diatomite (80 mesh) were immersed in $10 \mathrm{ml}$ of $1 \mathrm{~mol} / \mathrm{L} \mathrm{AlCl} 3 \cdot 6 \mathrm{H}_{2} \mathrm{O}$, a certain amount of 3mol/L NaOH was immediately added into the mixture and then shook at room temperature for $2 \mathrm{~h}$ in the oscillators. Then, the mixture was exposed to air for $12 \mathrm{~h}$ and discard the supernatant and afterwards dried in an oven at $105^{\circ} \mathrm{C}$ for $12 \mathrm{~h}$. Finally, the samples were grinded to 80 mesh and stored in the valve bag for further study. The prepared sample was named as Al-diatomite. The surface of diatomite and Al-diatomite was observed by using a scanning electron microscope (SEM) (FEI Quanta 200, Netherlands). The mineral phase of diatomite was characterized by X-ray diffraction (XRD) (Rigaku TTR III, Japan). X-ray fluorescence spectrometer (XRF) (Rigaku ZSX100e, Japan) provided us the element contents.

\subsection{Adsorption Experiments}

A stock solution (1000 mg/L) was prepared by dissolving $1.598 \mathrm{~g} \mathrm{~Pb}\left(\mathrm{NO}_{3}\right)_{2}$ (analytical grade) in $1 \mathrm{~L}$ of deionized water. All the solutions for lead removal experiments and analysis were prepared by an appropriate dilution of the stock solution. The $\mathrm{pH}$ of the lead solution was adjusted using $5 \mathrm{M} \mathrm{NaOH}$ and $\mathrm{HCl}$ solutions. $0.3 \mathrm{~g}$ of diatomite sample and $100 \mathrm{ml}$ of $\mathrm{Pb}\left(\mathrm{NO}_{3}\right)_{2}$ solution were added in $150 \mathrm{ml}$ conical flask and then were placed in a shaker with a speed of $100 \mathrm{rpm}$. $\mathrm{Pb}$ (II) remaining in the supernatant was analyzed by flame atomic absorption spectrophotometry (FAAS) (Varian AA240FS, American). Effects of adsorbent dose, $\mathrm{pH}$ of suspension, initial concentration and the reaction temperature were investigated

\section{Result and Discussion}

\subsection{Characterizations of Adsorbents}

The scanning electron microscope (Figure 1) shows that the main pattern of the diatomite (Figure 1(a)) was 


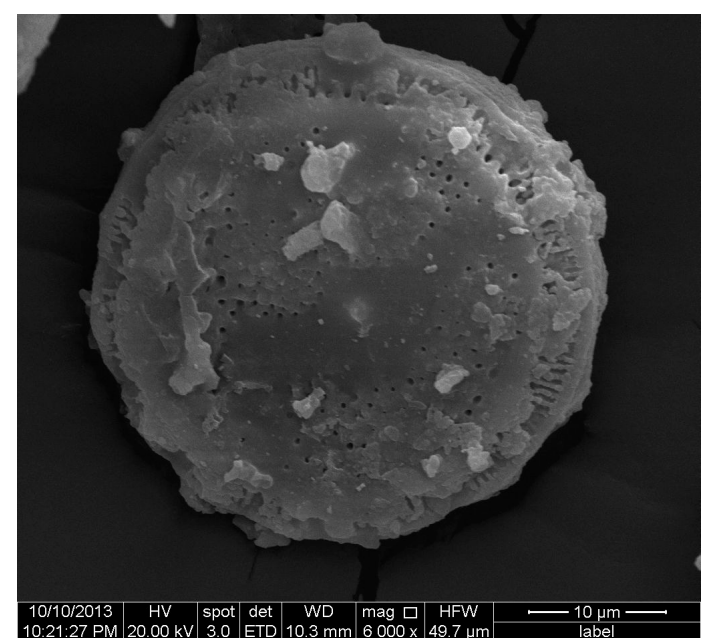

(a)

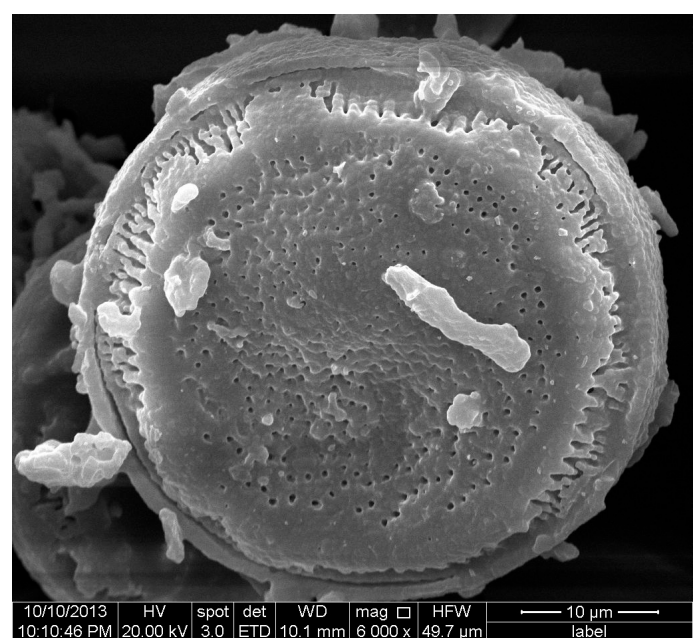

(b)

Figure 1. SEM images of diatomite (a); Al-diatomite (b).

discoid and the surface was porous structure. However, Al-diatomite (Figure 1(b)) was relatively uneven and a number of pores were filled, it illustrates that the expected aluminium compound formed in the interspaces. As can be seen from Figure 2, the main composition of diatomite and Al-diatomite were opal $\left(\mathrm{SiO}_{2} \cdot \mathrm{nH}_{2} \mathrm{O}\right)$ [16], nevertheless, after the modification, Bayerite knowing as $\mathrm{Al}(\mathrm{OH})_{3}$ was found in the XRD peak of the Al-diatomite, and the result of XRF in Table 1 also indicated the percentage of Al increased from 1.28\% to 9.30\%. This is because of the coating process by the product of $\mathrm{AlCl} 3 \cdot 6 \mathrm{H} 2 \mathrm{O}$ and $\mathrm{NaOH}$ solutions, followed that aluminum hydroxide compound has been successfully loaded at the diatomite. In Figure 3, the general range 3600 - 3100 $\mathrm{cm}^{-1}$ may be assigned to asymmetrical and symmetrical O-H stretching vibration modes for water of hydration and the $1670-1600 \mathrm{~cm}^{-1}$ region to $\mathrm{O}-\mathrm{H}$ bending vibration modes [17]. The presence of $\mathrm{SiO}_{2}$ is verified by ad-sorption bands at $1068 \mathrm{~cm}^{-1}$ of asymmetric Si-O-Si stretching vibrations, and Si-O-Si bending vibrations at $469 \mathrm{~cm}^{-1}$ [18]. In addition, the adsorption band at $791 \mathrm{~cm}^{-1}$ and $618 \mathrm{~cm}^{-1}$ are ascribed to Al-O absorption bands [19]. As Al-diatomite shown, the peaks at $3421 \mathrm{~cm}^{-1}$ and $1641 \mathrm{~cm}^{-1}$ were attributed to the stretching vibration of absorbed water and zeolitic water [7]. It indicated that the group composition of diatomite changes as modification and this explained why the adsorption capacity of Al-diatomite became stronger.

\subsection{Effect of Adsorbent Dosage}

The adsorbent dose is an important parameter for the determining of the adsorb-ability of adsorbent at a given initial condition. In this study, the effect of adsorbent dose on the lead removal was studied at $\mathrm{pH} 5.0 \pm 0.1$, room temperature and $10 \mathrm{mg} / \mathrm{L}$ of lead for $2 \mathrm{~h}$. As the result shown in Figure 4(a), it was observed that the adsorption efficiency of $\mathrm{Pb}$ (II) increased from $20.27 \%$ to $99.02 \%$ with the increasing dose of Al-diatomite from 1 $\mathrm{g} / \mathrm{L}$ to $20 \mathrm{~g} / \mathrm{L}$. However, the per unit of adsorption capacity declined with the dose increasing, as we can see, the adsorption capacity decreased slowly after a dose of $3 \mathrm{~g} / \mathrm{L}$. This is because at low adsorbent content, all types of surface sites are exposed for sorption and the surface reaches saturation faster, leading to a higher sorption capacity. But at higher hematite concentrations the availability of higher energy sites decreases and with a larger fraction of lower energy sites occupied, a lower sorption capacity is found [20]. In addition, a higher amount of adsorbent increases the probability of collision between solid particles and thus particle aggregation, causing a decrease in the total surface area and an increase in diffusion path length, both of which contribute to the decrease in sorption capacity [21].

\subsection{Effect of the pH}

The $\mathrm{pH}$ of a solution could obviously influence the extent of lead adsorption, especially the existential state of lead in the solution and charge the surface of adsorption. As lead ion precipitates when the $\mathrm{pH}$ of solution is alkaline, the effect of $\mathrm{pH}$ was studied by varying the $\mathrm{pH}$ of lead solution from 4.0 to 6.5, $3 \mathrm{~g} / \mathrm{Lad}$ sorbent dose, 


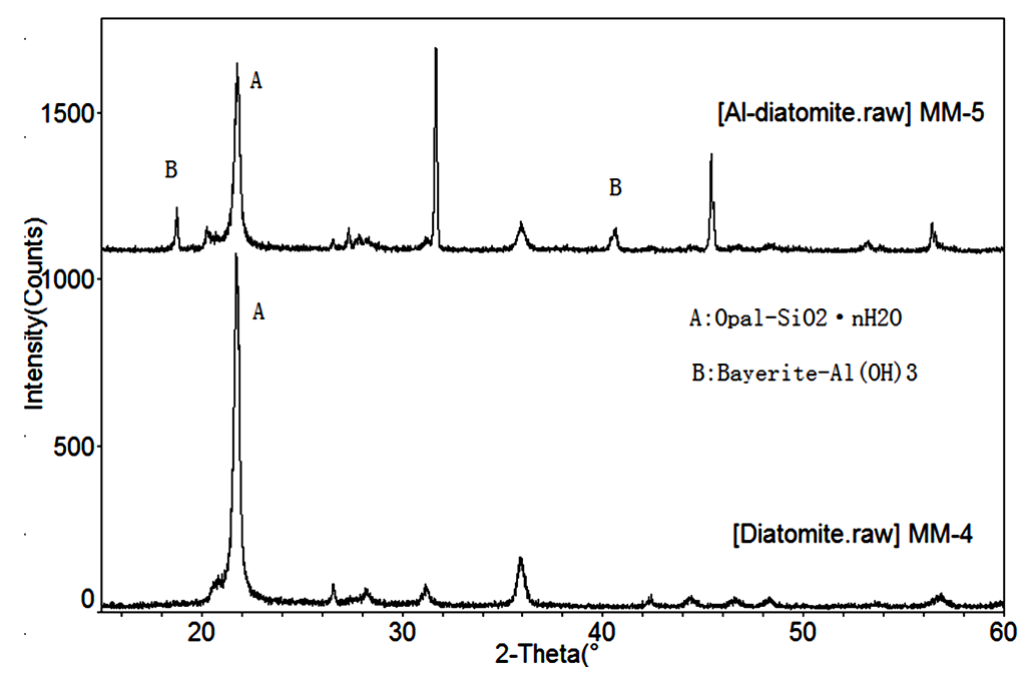

Figure 2. XRD of diatomite and Al-diatomite.

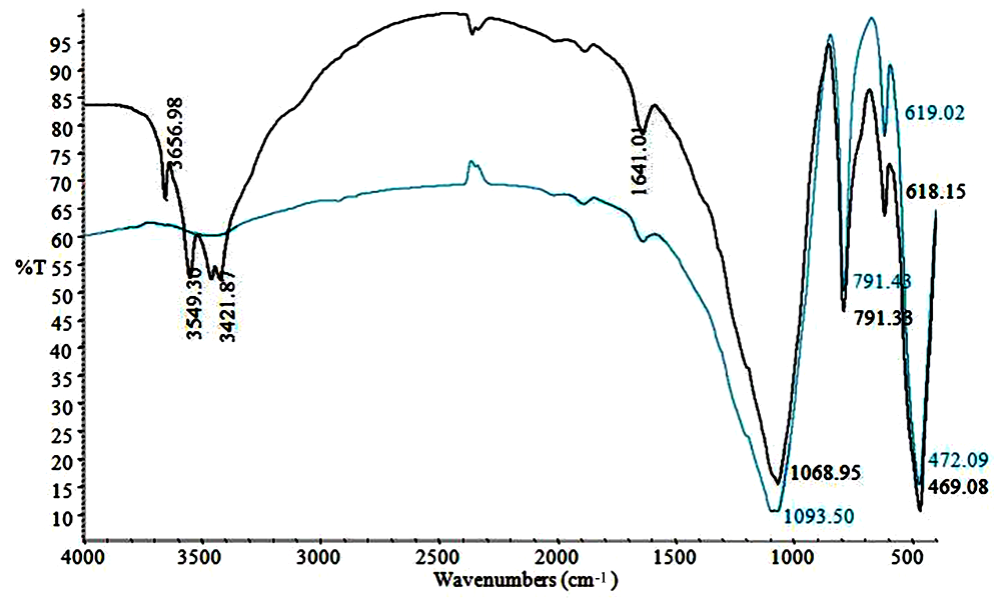

Figure 3. Infrared spectroscopy images of diatomite (a), Al-diatomite (b).

Table 1. Elementary composition of diatomite and Al-diatomite from XRF analysis.

\begin{tabular}{ccccccccc}
\hline Elementary composition (wt \%) & $\mathrm{O}$ & $\mathrm{Si}$ & $\mathrm{Al}$ & $\mathrm{Fe}$ & $\mathrm{K}$ & $\mathrm{Na}$ & $\mathrm{Mg}$ \\
\hline Diatomite & 53.40 & 39.62 & 1.28 & 1.31 & 0.44 & 1.40 & 0.22 \\
Al-diatomite & 50.66 & 22.61 & 9.30 & 0.52 & 0.24 & 5.51 & 0.11 \\
\hline
\end{tabular}

room temperature and $10 \mathrm{mg} / \mathrm{L}$ of lead for $2 \mathrm{~h}$. The other experimental conditions were extremely same as described in the effect of dose. It can be seen from Figure 4(b) that the lead sorption by Al-diatomite was increased from $41.7 \%$ to $74.5 \%$ when the $\mathrm{pH}$ of the solution increased from 4 to 5.5 and from $\mathrm{pH} 5.5$ to 6.6 , the sorption maintains the maximum value of $74.5 \%$. This may be due to the fact that a mass of $\mathrm{H}+$ surrounded the drill way of adsorbent and occupied the adsorption site when the $\mathrm{pH}$ was low. Then lead was prevented into the drill way and it was adverse to the ion exchange adsorption between adsorption and lead.

\subsection{Effect of the Initial Concentration}

The effect of initial concentration on the lead removal was studied at $3 \mathrm{~g} / \mathrm{Lad}$ sorbent dose, $\mathrm{pH} 5.0 \pm 0.1$ and room temperature for 2 h. It can be seen from Figure 4(c) that the adsorption capacity of lead ions by Al-diatomite increased with the raising of initial concentration, but the adsorption efficiency decreased. It was 


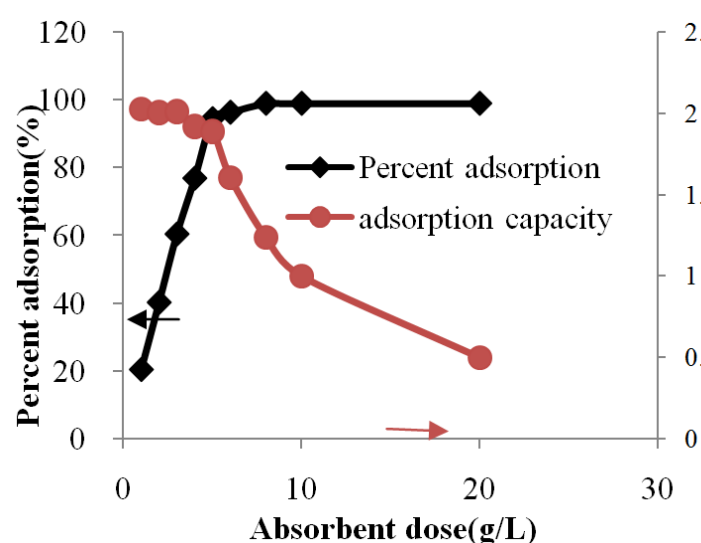

(a)

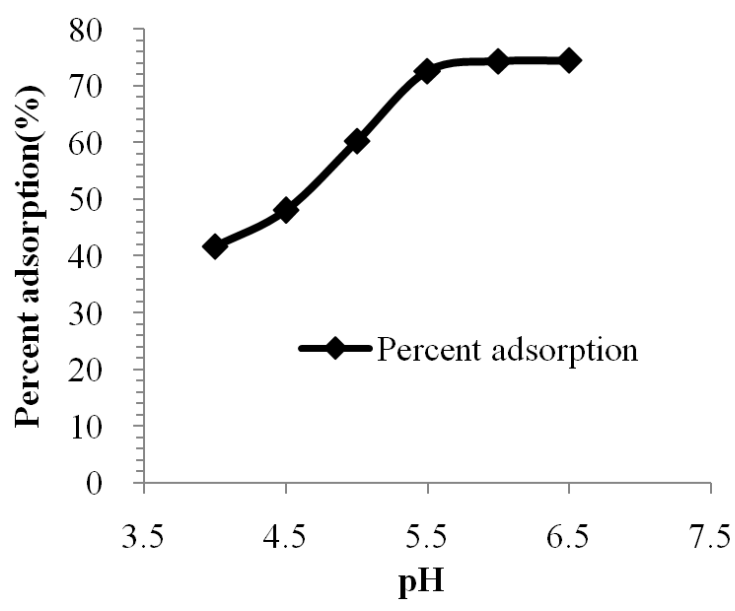

(c)

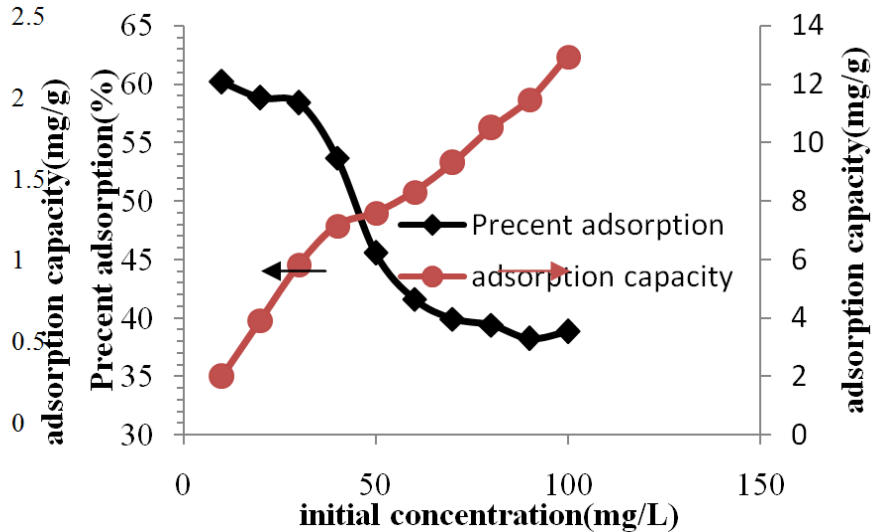

(b)

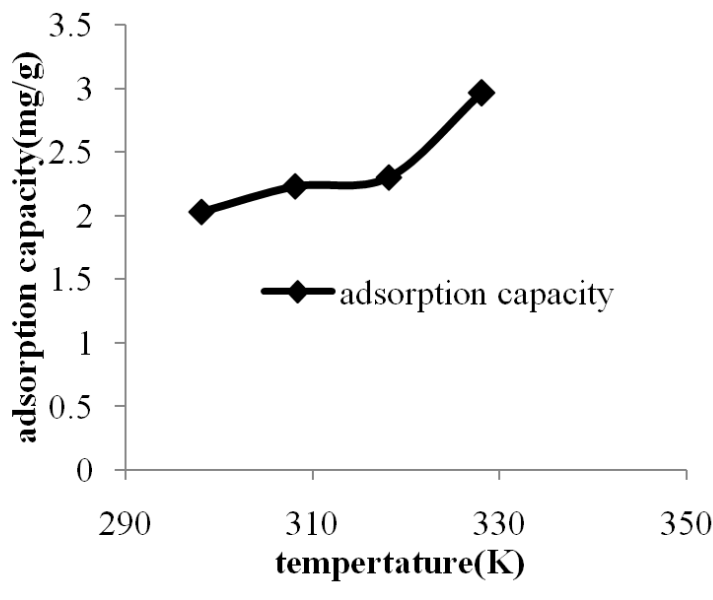

(d)

Figure 4. Effect of adsorbent dose (a); pH of suspension (b); initial concentration (c) and the reaction temperature (d) on lead adsorption percentage and adsorption capacity.

due to an increase of the amount of lead ions available to binding sites of adsorbents. Though at $100 \mathrm{mg} / \mathrm{L}$ lead concentration, the active sites were not saturated and adsorption capacity doesn't approach a constant value.

\subsection{Effect of Temperature}

The effect of temperature on lead removal was studied at the solution temperature ranged from 298.15 to 328.15 $\mathrm{K}, 3 \mathrm{~g} / \mathrm{Lad}$ sorbent dose, $\mathrm{pH} 5.0 \pm 0.1$, and $10 \mathrm{mg} / \mathrm{L}$ of lead for $2 \mathrm{~h}$. It was found that the adsorption of $\mathrm{Pb}$ (II) on diatomite was promoted at higher temperature, adsorption capacity increased from $2.03 \mathrm{mg} / \mathrm{g}$ to $2.96 \mathrm{mg} / \mathrm{g}$ with the increase of temperature for Al-diatomite (Figure 4(d)), It demonstrated that the rise in temperature increased the binding tendency of the lead ions onto the interface and thereby strengthened the extent of adsorption [22]. One possible interpretation of this phenomenon was that the $\mathrm{Pb}$ (II) ions were well hydrated, in order to be adsorbed on the diatomite, they had to lose the hydration shell which needed energy, so the removal of water molecules from $\mathrm{Pb}$ (II) ions was an endothermic process in essence [23].

Thermodynamics parameters for adsorption process, such as, the enthalpy change $(\Delta H)$ and entropy change $(\Delta S)$, were calculated from the slope and intercept of the straight line of ln versus $1 / T$ according to the following form [24]:

$$
\begin{gathered}
K D=C_{A d} / C_{e} \\
\Delta G=-R T \ln K D \\
\Delta G=\Delta H-T \Delta S
\end{gathered}
$$


where $C_{A d}$ and $C_{e}(\mathrm{mg} / \mathrm{L})$ are the concentration of adsorbed and equilibrium lead, respectively, $K c$ is the equilibrium constant, $R$ is the gas constant $\left(8.314 \mathrm{~J} \mathrm{~mol}^{-1} \cdot \mathrm{K}^{-1}\right)$, and $\mathrm{T}$ is the absolute temperature $(\mathrm{K})$.

Values of $\Delta H, \Delta G$ and $\Delta S$ were shown in Table 2. It was clear that the free energy ( $\Delta G)$ of $\mathrm{Pb}$ (II) adsorption on Al-diatomite was all negative and decreased with the rise in temperature, which demonstrated that the adsorption process was spontaneous. The endothermic process was confirmed by the positive value of enthalpy change $(\Delta H)$. The positive value of entropy change $(\Delta S)$ indicated the increase in randomness of the ongoing process and the adsorption reactions were spontaneous with a good affinity. As enthalpy change absolute value of physical adsorption is $0-20 \mathrm{~kJ} / \mathrm{mol}$. In another word, enthalpy change absolute value of chemical adsorption is greater than $20 \mathrm{~kJ} / \mathrm{mol}$. It was found that $\mathrm{Pb}$ (II) adsorption on Al-diatomite was chemical adsorption in consideration of enthalpy change absolute value in Table 2.

\subsection{Adsorption Isotherm}

Langmuir and Freundlich isotherm models described the relationship between the concentrations of absorbed lead and lead in solution when the adsorption is in dynamic balance with that on the liquid-solid interface at a given temperature. Langmuir isotherm was based on the theory that the monolayer adsorption and assumes that the surface of sorbent was composed of amounts of homogeneous adsorption sites. Langmuir isotherm equation [25] was given as:

$$
Q_{e}=Q_{\max } b C_{e} /\left(1+b C_{e}\right)
$$

where $Q_{\max }(\mathrm{mg} / \mathrm{g})$ and $C_{e}(\mathrm{mg} / \mathrm{L})$ are maximum adsorption capacity and equilibrium concentration, $b$ represents a constant related to affinity and energy of blinding sites.

Freundlich isotherm equation is derived to describe the multilayer adsorption and the heterogeneous surfaces of absorbent illustrate that the adsorption equilibrium constants are related to the coverage of surfaces. Freundlich isotherm equation [26] was given as:

$$
Q_{e}=K_{F} C_{e} 1 / n
$$

where $K_{F}$ and $n$ are Freundlich coefficients relating to adsorption capacity and intensity respectively.

The Langmuir and Freundlich isotherm of $\mathrm{Pb}$ (II) on Al-diatomite are shown in Figure 5 (The experiment conditions can refer to 3.4). As the parameters shown in Table 3, Compared with Langmuir isotherm $\left(R^{2}=\right.$ 0.933), Freundlich isotherm $\left(R^{2}=0.960\right)$ model was better fitted to describe the ad-sorption characteristics of $\mathrm{Pb}(\mathrm{II})$ on Al-diatomite. In Freundlich parameters, $\mathrm{n}$ value (1.650) indicated the high bond strength between absorbate and adsorbent, and it also illustrated the adsorbent surface was heterogeneous [27].

\subsection{Lead removal by Natural Diatomite}

In order to compare the effect of lead removal between diatomite and Al-diatomite, The conditions on lead removal was studied at $3 \mathrm{~g} / \mathrm{Lad}$ sorbent dose, $\mathrm{pH} 5.0 \pm 0.1$, room temperature and $10 \mathrm{mg} / \mathrm{L}$ of lead for $2 \mathrm{~h}$. It canbe seen from Table 4. It was found that the percent adsorption of $\mathrm{Pb}$ (II) on diatomite was only $12.06 \%$ and ad

Table 2. Thermodynamic parameters for the adsorption of lead on Al-diatomite.

\begin{tabular}{cccc}
\hline$T(\mathrm{~K})$ & $\Delta G(\mathrm{~kJ} / \mathrm{mol})$ & $\Delta H(\mathrm{~kJ} / \mathrm{mol})$ & $\Delta S(\mathrm{~J} / \mathrm{mol} \cdot \mathrm{K})$ \\
298.15 & -0.62 & & \\
308.15 & -1.98 & 39.96 & 136.11 \\
318.15 & -3.34 & & \\
328.15 & -4.70 & & \\
\hline
\end{tabular}

Table 3. Isotherm parameters for the for lead adsorption onto Al-diatomite.

\begin{tabular}{ccccccc} 
& \multicolumn{3}{c}{ Langmuir isotherm } & & \multicolumn{2}{c}{ Freundlich isotherm } \\
\hline & $Q_{\max }(\mathrm{mg} / \mathrm{g})$ & & $b(\mathrm{~L} / \mathrm{mg})$ & $R^{2}$ & $K_{F}$ & $n$ \\
\hline 17.4825 & 0.0328 & 0.9329 & 1.0408 & 1.6499 & 0.9599 & $R^{2}$ \\
\hline
\end{tabular}


Table 4. Lead removal by natural diatomite.

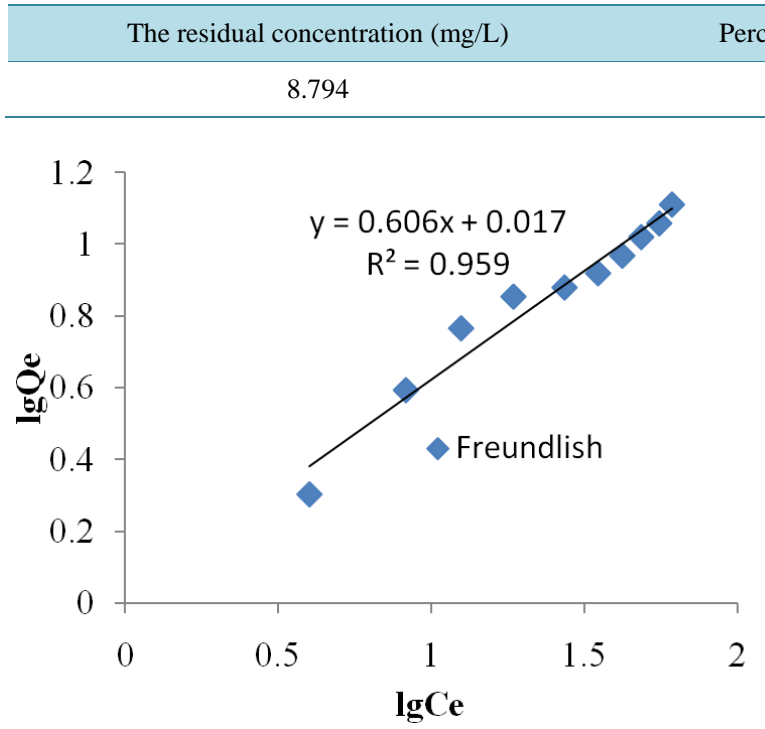

(a)
Percent adsorption (\%) $12.06 \%$

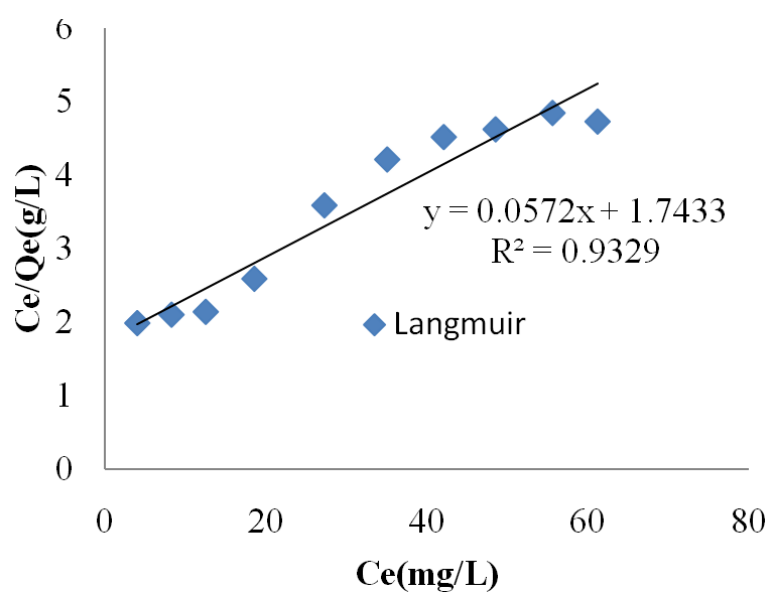

(b)
Adsorption capacity (mg/g) 0.402

Figure 5. Isotherm modeling of lead adsorption on the Al-diastomite (a) Langmuir isotherm; (b) Freundlich isotherm.

sorption capacity was $0.402 \mathrm{mg} / \mathrm{g}$. However, in the same experiment conditions, the percent adsorption of lead removal by Al-diatomite could reach to $61.36 \%$.

\section{Conclusion}

In this paper, aluminum was utilized to coat on the surface of diatomite for the efficient removal of lead. FTIR, $\mathrm{XRD}$, and SEM results show that aluminium com-pound was successfully coated on the surface of diatomite. Comparing with the natural diatomite, the adsorption efficiency for the lead ions increased from $12.06 \%$ to $61.36 \%$, indicating that Al-diatomite was an effective absorbent for removing lead ions from wastewater. The free energy $(\Delta G)$ of $\mathrm{Pb}$ (II) adsorption on Al-diatomite was all negative and decreased with the rise in temperature. It demonstrated that the adsorption process was spontaneous. The enthalpy change absolute value illustrated that $\mathrm{Pb}$ (II) adsorption on Al-diatomite was chemical adsorption. The adsorbent surface was heterogeneous as the equilibrium data of Al-diatomite samples well fitted to Freundlich isotherm model. Therefore, Al-diatomite presents a good potential application in the treatment of lead wastewater.

\section{References}

[1] Fan, Q.H., Li, Z., Zhao, H.G., Jia, Z.H., Xu, J.Z. and Wu, W.S. (2009) Sorption of Pb(II) on Palygorskite from Aqueous Solution: Effects of pH, Ionic Strength and Temperature. Applied Clay Science, 45, 111-116. http://dx.doi.org/10.1016/j.clay.2009.04.009

[2] Zha, F., Huang, W.Y., Wang, J.Y., Chang, Y., Ding, J. and Ma, J. (2013) Kinetic and Thermodynamic Aspects of Arsenate Adsorption on Aluminum Oxide Modified Palygorskitenano-Composites. Chemical Engineering Journal, 215216, 579-585. http://dx.doi.org/10.1016/j.cej.2012.11.068

[3] Irania, M., Amjadib, M. and Mousavian, M.A. (2011) Comparative Study of Lead Sorption onto Natural Perlite, Dolomite and Diatomite. Chemical Engineering Journal, 178, 317-323. http://dx.doi.org/10.1016/j.cej.2011.10.011

[4] Razo, I., Carrizales, L., Castro, J., et al. (2004) Arsenic and Heavy Metal Pollution of Soil, Water and Sediments in a Semi-Arid Climate Mining Area in Mexico. Water Air and Soil Pollution, 152, 129-152. http://dx.doi.org/10.1023/B:WATE.0000015350.14520.c1

[5] Lin, S.H., Lai, S.L. and Leu, H.G. (2000) Removal of Heavy Metals from Aqueous Solution by Chelating Resin in a Multistage Adsorption Process. Journal of Hazardous Materials, 76, 139-153. http://dx.doi.org/10.1016/S0304-3894(00)00207-7

[6] Wang, Y.H., Lan, Y. and Hu, Y.H. (2008) Adsorption mechanisms of Cr(VI) on the modified bauxite tailings. Miner- 
als Engineering, 21, 913-917. http://dx.doi.org/10.1016/j.mineng.2008.04.003

[7] Sheng, G.D., Wang, S.W., Hu, J., Lu, Y., Li, J.X., Dong, Y.H. and Wang, X.K. (2009) Adsorption of Pb(II) on Diatomite as Affected via Aqueous Solution Chemistry and Temperature. Colloids and Surfaces A, 339, 159-166. http://dx.doi.org/10.1016/j.colsurfa.2009.02.016

[8] Eren, E., Afsin, B. and Onal, Y. (2009) Removal of Lead Ions by Acid Activated and Manganese Oxide-Coated Bentonite. Journal of Hazardous Materials, 161, 677-685. http://dx.doi.org/10.1016/j.jhazmat.2008.04.020

[9] Deng, Y.H., Gao, Z.Q., Liu, B.Z., Hu, X.B., Wei, Z.B. and Sun, C. (2013) Selective Removal of Lead from Aqueous Solutions by Ethylenediamine-Modified Attapulgite. Chemical Engineering Journal, 223, 91-98. http://dx.doi.org/10.1016/j.cej.2013.03.020

[10] Chen, H. and Wang, A.Q. (2007) Kinetic and Isothermal Studies of Lead Ion Adsorption onto Palygorskite Clay. Journal of Colloid and Interface Science, 307, 309-316. http://dx.doi.org/10.1016/j.jcis.2006.10.054

[11] Liang, X.F., Xu, Y.M., Wang, L., Sun, Y.B., Lin, D.S., Sun, Y., Qin, X. and Wan, Q. (2013) Sorption of Pb2+ on mercapto functionalized sepiolite. Chemosphere, 90, 548-555. http://dx.doi.org/10.1016/j.chemosphere.2012.08.027

[12] Jia, Y.X., Han, W., Xiong, G.X. and Yang, W.S. (2008) Layer-by-Layer Assembly of $\mathrm{TiO}_{2} \mathrm{Colloids}$ onto Diatomite to Build Hierarchical Porous Materials. Journal of Colloid and Interface Science, 323, 326-331. http://dx.doi.org/10.1016/j.jcis.2008.04.020

[13] Al-Ghouti, M.A., Khraisheh, M.A.M., Allen, S.J. and Ahmad, M.N. (2003) The Removal of Dyes from Textile Wastewater: A Study of the Physical Characteristics and Adsorption Mechanisms of Diatomaceous Earth. Journal of Environmental Management, 69, 229-238. http://dx.doi.org/10.1016/j.jenvman.2003.09.005

[14] Al-Degs, Y., Khraisheh, M.A.M. and Tutunji, M.F. (2001) Sorption of Lead Ions on Diatomite and Manganese Oxides Modified Diatomite. Water Research, 15, 3724-3728. http://dx.doi.org/10.1016/S0043-1354(01)00071-9

[15] M.A.M. Khraisheh, Y.S. Al-degs, W.A.M. Mcminn, (2004) Remediation of Wastewater Containing Heavy Metals Using Raw and Modified Diatomite. Chemical Engineering Journal, 99, 177-184. http://dx.doi.org/10.1016/j.cej.2003.11.029

[16] Li, X.W., Li, X.X. and Wang, G.C. (2007) Surface Modification of Diatomite Using Polyaniline. Materials Chemistry and Physics, 102, 140-143. http://dx.doi.org/10.1016/j.matchemphys.2006.11.014

[17] Apte, S.K., Naik, S.D., Sonawane, R.S., Kalew, B.B. and Baeg, J.O. (2007) Synthesis of Nanosize-Necked Structure $\alpha$ and $\gamma-\mathrm{Fe}_{2} \mathrm{O}_{3}$ and Its Photocatalytic Activity. Journal of the American Ceramic Society, 90, 412-414. http://dx.doi.org/10.1111/j.1551-2916.2006.01424.x

[18] Wu, G.M., Lu, H.Y., Wang, J., Shen, J., Zhou, B., Zhang, Q.Y. and Deng, Z.S. (2002) Ambient Pressure Preparation and Strengthening of Silica Aerogel Films. Acta Physica Sinica, 51, 104.

[19] Zhang, Y., Zhang, C., Zhang, Y., Zhang, G., Liu, S. and Xu, Z. (2011) Development of $\mathrm{Al}_{2} \mathrm{O}_{3}$ Film on Diatomite for Treating Wastewater Containing Anionic Polyacrylamide. Chemical Engineering \& Technology, 34, $2016-2021$. http://dx.doi.org/10.1002/ceat.201100307

[20] Huang, J.H., Liu, Y.F. and Wang, X.G. (2008) Selective Sorption of Tannin from Flavonoids by Organically Modified Attapulgite Clay. Journal of Hazardous Materials, 160, 382-387. http://dx.doi.org/10.1016/j.jhazmat.2008.03.008

[21] Zhao, D.L., Chen, C.L., et al. (2011) Effect of Environmental Conditions on the Retention Behaviour of Pb(II) by Hematite. Journal of Chemical Technology and Biotechnology, 86, 1099-1106. http://dx.doi.org/10.1002/jctb.2623

[22] Chen, N., Zhang, Z.Y., Feng, C.P., Li, M., Zhu, D.R. and Sugiura, N. (2011) Studies on Fluoride Adsorption of Iron-Impregnated Granular Ceramics from Aqueous Solution. Materials Chemistry and Physics, 125, 293-298. http://dx.doi.org/10.1016/j.matchemphys.2010.09.037

[23] Chen, C.L. and Wang, X.K. (2006) Adsorption of Ni(II) from Aqueous Solution Using Oxidized Multiwall Carbon Nanotubes. Industrial \& Engineering Chemistry Research, 45, 9144-9149. http://dx.doi.org/10.1021/ie060791z

[24] Khan, A.A. and Singh, R.P. (1987) Adsorption Thermodynamics of Carbofuran on Sn (IV) Arsenosicicate in $\mathrm{H}^{+}, \mathrm{Na}^{+}$ and $\mathrm{Ca}^{2+}$ Forms. Colloids and Surfaces, 24, 33-42. http://dx.doi.org/10.1016/0166-6622(87)80259-7

[25] Pahlavanzadeh, H., Keshtkar, A.R., Safdari, J. and Abadi, Z. (2010) Biosorption of Nickel(II) from Aqueous Solution by Brown Algae: Equilibrium, Dynamic and Thermodynamic Studies. Journal of Hazardous Materials, 175, 304-310. http://dx.doi.org/10.1016/j.jhazmat.2009.10.004

[26] Pokhrel, D. and Viraraghavan, T. (2008) Arsenic Removal from an Aqueous Solution by Modified A. niger Biomass: Batch Kinetic and Isotherm Studies. Journal of Hazardous Materials, 150, 818-825. http://dx.doi.org/10.1016/j.jhazmat.2007.05.041

[27] Dogan, M., Alkan, M., Türkyilmaz, A. and Özdemir, Y. (2004) Kinetics and Mechanism of Removal of Methylene Blue by Adsorption onto Perlite. Journal of Hazardous Materials, 109, 141-148. http://dx.doi.org/10.1016/j.jhazmat.2004.03.003 